\title{
Meta-Analysis and Meta-Regression of the Prevalence of Diabetic Peripheral Neuropathy Among Patients with Type 2 Diabetes Mellitus
}

\author{
Lidiane Ribeiro de Souza1, Debora Debiasi ${ }^{1}$, Luciane Bisognin Ceretta1,2, \\ Priscyla Waleska Simões ${ }^{1,2}$, Lisiane Tuon ${ }^{1,2}$
}

\section{Abstract}

The aim of the present study was to investigate the prevalence of diabetic peripheral neuropathy (DPN) among patients with type 2 diabetes mellitus (DM) using a systematic review and meta-analysis. An electronic search was conducted in the PubMed, Embase, Cochrane and other databases. This search employed articles published from July 1983 to December 2014. Only cross-sectional studies conducted with individuals aged 18 to 75 years old that investigated the prevalence of DPN among type 2 DM were included. Meta-regression and sensitivity analyses were performed to investigate the sources of heterogeneity. Publication bias was assessed via funnel plots and the Begg test. The meta-analysis was performed using the R 3.1.1 software. The study selection process resulted in the inclusion of 27 articles in the metaanalysis. In total, the occurrence of DPN was investigated in 16.337 individuals with type 2 DM. The global prevalence of DPN among patients with type 2 DM was 35.78\% (95\% Cl: 27.86-44.55\%). The sensitivity analysis by continent where the studies were performed showed that the prevalence of DPN was higher in Europe $(48.14 \%$; 95\% Cl: 33.31-63.30\%). A meta-regression analysis did not 44.91\%). The any cofactors as a cause of the heterogeneity. Our data suggest that the prevalence of DPN among individuals with type 2 DM is high. Due to the impact of the complications of DPN on the quality of life of the affected patients and the cost of care for these complications, this condition should be considered a significant public health problem.
1 Multidisciplinary Residency Program in Primary Care / Family Health. Universidade do Extremo Sul Catarinense (UNESC), Criciúma, SC, Brazil.

2 Graduate Program in Public Health (PPGSCol). Universidade do Extremo Sul Catarinense (UNESC), Criciúma, SC, Brazil.

Contact information:

\section{Lisiane Tuon, Priscyla Waleska} Simões.

Multidisciplinary Residency Program in Primary Care/Family Health. Universidade do Extremo Sul Catarinense (UNESC).

Address: Universidade do Extremo Sul Catarinense (UNESC). Av Universitária, 1105. Bairro Universitário. CEP: 88803110. Criciúma, SC, Brasil.

Tel: $+55483431-2500$

$\equiv$ Itb@unesc.net $\risingdotseq$ pri@unesc.net 


\section{Introduction}

Diabetes mellitus (DM) is one of the most common metabolic diseases, and the number of cases has increased worldwide. According to the International Diabetes Federation (IDF), the number of patients with diabetes will increase from $387 \mathrm{mi}-$ llion in 2014 to 592 million in 2035. With a global prevalence of $8.3 \%$, DM represents a worldwide problem [1].

This pandemic mainly involves type 2 DM, which remains asymptomatic over a long period of time in many cases and is only diagnosed once the associated complications appear [2].

The most common neuropathies are symmetrical generalized polyneuropathy, especially the distal symmetric polyneuropathy or sensorimotor, called peripheral diabetic neuropathy, followed by the autonomic, sensory-acute; and focal and multifocal, less frequents $[3,4]$.

More than half of all individuals with diabetes exhibit one or more microvascular complications, including diabetic nephropathy (DN), diabetic peripheral neuropathy (DPN), or diabetic retinopathy (DR), which have a serious negative impact on the quality of life of patients $[5,6]$.

DPN is a well-known microvascular complication of type 2 DM. DPN is attributed to chronic hyperglycemia and is defined as the presence of peripheral nerve dysfunction in individuals with diabetes after the exclusion of other causes. DPN is associated with infections and is directly associated with increased risk for foot ulceration and nontraumatic amputation. The estimates of foot infections in type 2 DM patients range from a risk of $4 \%$ to $7 \%$ annually $[2,7]$.

The symptoms of DPN are intermittent and include persistent limb pain with a tingling or burning sensation, among others. DPN is one of the most debilitating factors for patients. The prevalence of DPN ranges from $30 \%$ to $90 \%$. Patients might also develop hypoesthesia or paresthesia with numbness or an "electric shock" sensation [8].
Based on the afore mentioned considerations, as well as the lack of systematic reviews and metaanalyses assessing the association of DPN with DM the results of the present study might contribute to formulating strategies for early screening of DPN patients to achieve more effective diabetic control and reduce the risk of ulceration, gangrene, amputation, and other related consequences [8].

Thus, the aim of the present study was to assess the prevalence of DPN among patients with type 2 DM via a systematic review and meta-analysis.

\section{Methods}

\section{Search strategy}

An electronic search was conducted in the MEDLINE (via PubMed), Embase, LILACS [Literatura Latino-Americana e do Caribe em Ciências da Saúde (Latin American and Caribbean Health Sciences Literature)], Scopus, Cochrane Central Register of Controlled Trials, IBECS [Indice Bibliográfico Español de Ciencias de la Salud (Spanish Bibliographic Index on Health Sciences)], BIOSIS, and Web of Science databases and was restricted to articles published from July 1983 to December 2013 based on the following MeSH keywords and synonyms: "diabetic neuropathy", "diabetic neuropathies" combined with "Diabetes Mellitus, Type 2", "2 diabetes", "type 2 diabetes", "type 2 diabetes mellitus", and "2 diabetes mellitus type". The search terms were combined using the Boolean operators "AND", "OR", and "NOT".

The references listed in all of the primary studies were retrieved, and a search was also performed in the gray literature. No restrictions regarding publication language were applied, and the search was limited to studies on humans.

The titles and abstracts of articles retrieved via the application of the aforementioned search strategy to the databases were independently analyzed by four researchers. The studies considered to 
be potentially relevant and that met the required criteria were selected for full-text reading, which was performed by four researchers. In both steps, instances of disagreement regarding the inclusion or exclusion of studies were resolved by consensus with additional researchers.

\section{Study selection}

Cross-sectional studies that included individuals aged 18 to 75 years and that assessed the prevalence of DPN among patients with type 2 DM were included for analysis. Regarding the diagnostic criteria used, individuals with fasting blood glucose levels $\geq 7 \mathrm{mmol} / \mathrm{L}$, casual glucose levels $>11,11 \mathrm{mmol} / \mathrm{L}$, associated with the presence of classic symptoms of diabetes, blood glucose levels $>11,11 \mathrm{mmol} / \mathrm{L}$, two hours after the intake of a $75 \mathrm{~g}$ dose of glucose (oral glucose tolerance test), glycated hemoglobin (HbA1c) levels $\geq 6.5 \%$ or under medical follow up after having been diagnosed with diabetes before the onset of the corresponding studies were considered diabetic.

The diagnosis of DPN was considered to be adequate when specific validated tests were used, electroneuromyography was performed, and the clinical diagnosis was established by a properly trained professional [9-13].

To minimize interference with the diagnosis of DPN, individuals with myopathies, peripheral vascular diseases, central or peripheral neurological disorders not associated with DM, hypothyroidism, alcoholism, poisoning, moderate-to-severe vitamin deficiencies, uremia, and paraneoplastic or inflammatory conditions were excluded from the metaanalysis.

\section{Data synthesis and statistical analysis}

The following data were recorded from the articles: publication year, country, patient ages and genders, and the number of patients with DPN and type 2 DM.

In the meta-analysis, the data regarding the prevalence of DPN among individuals with type 2 DM were clustered using the random effects method $[14,15]$ heterogeneity was calculated using the $\tau^{2}$ and Cochran's Q tests, and inconsistency was expressed as $I^{2}[16,17]$, which describes the percentage of variability that is due to heterogeneity rather than chance [15].

Because heterogeneity was observed, sensitivity analyses were performed to identify the associated cofactors (such as continent) that accounted for the heterogeneity. Potential cofactors associated with heterogeneity (publication year, duration of diabetes, duration of DPN, and average $\mathrm{HbA} 1 \mathrm{c}$ level) were also analyzed by a meta-regression [15, 18].

The possible occurrence of publication bias (tendency not to publish studies with negative results) was investigated using the Begg test [19] and analysis by funnel plots [20]. Each point in the funnel plots represents a study, its effect measure, or the prevalence and standard error [20]. A logit transformation of prevalence was performed in each included study to analyze the publication bias [20].

The meta-analysis was performed with $\mathrm{R}$ 3.1.1 software (Comprehensive R Archive Network, http:// cran.r-project.org/), and the results were represented as forest plots [21-23].

\section{Results}

The database searches yielded 635 studies eligible for analysis of titles and abstracts. However, 450 articles were excluded due to their experimental or clinical design or association with other diseases, or because they did not report data on the occurrence of DPN among individuals with type 2 DM. As a result, only 186 articles were selected for full-text reading.

Following full-text reading, 158 studies were excluded due to reporting of insufficient data, data duplication, the presence of associated diseases, or meeting the exclusion criteria. Thus, 27 articles were selected for the meta-analysis. The study selection process is depicted in Figure $\mathbf{1 .}$ 
Figure 1: Flowchart representing the process of study selection .

636 of records identified through database searching
0 of additional records identified through other sources

185 of full-text articles assessed for eligibility

158 of full-text articles excluded:

insufficient data associated diseases

\section{7 of studies included in qualitative synthesis}

27 of studies included in quantitative synthesis (meta-analysis)

Among the included studies, 08 were conducted in Europe, 11 in Asia, six in the Americas, and two in Oceania, and all studies were published from 1984 to 2013. In total, the occurrence of DPN was analyzed in 16.337 individuals with type 2 DM (cases) (Table 1). The average global prevalence of DPN was 35.78\% (95\% confidence interval (CI): 27.86\%$44.55 \%)$ varying from $8.43 \%(95 \% \mathrm{Cl}: 6.21 \%-$

Table 1. Studies included in the meta-analysis.

\begin{tabular}{|c|c|c|c|c|c|c|c|c|}
\hline Author & Country & Continent & $\begin{array}{l}\text { Patients } \\
\text { with DPN/ } \\
\text { T2DM }\end{array}$ & $\begin{array}{c}\text { Prevalence (T2DM) } \\
\%(95 \% \mathrm{Cl})\end{array}$ & $\begin{array}{c}\text { Men } \\
\text { with } \\
\text { T2DM }\end{array}$ & $\begin{array}{l}\text { Women } \\
\text { with } \\
\text { T2DM }\end{array}$ & $\begin{array}{l}\text { Men } \\
\text { with } \\
\text { DPN }\end{array}$ & $\begin{array}{c}\text { Women } \\
\text { with } \\
\text { DPN }\end{array}$ \\
\hline $\begin{array}{l}\text { Abougalambou et al. } \\
2012 \text { [24] }\end{array}$ & $\begin{array}{l}\text { Saudi } \\
\text { Arabia }\end{array}$ & Asia & $589 / 1077$ & $54.60(51.57-57.60)$ & 476 & 601 & & \\
\hline Acker et al. 2009 [25] & Belgium & Europe & $389 / 767$ & $50.72(47.12-54.31)$ & 436 & 331 & & \\
\hline $\begin{array}{l}\text { Al-Maskari and El-Sadig } \\
2007 \text { [26] }\end{array}$ & $\begin{array}{c}\text { Arab } \\
\text { Emirates } \\
\text { United }\end{array}$ & Asia & $156 / 423$ & 36.88 (32.27-41.67) & & & & \\
\hline $\begin{array}{l}\text { Bagavathiappan et al. } \\
2010 \text { [27] }\end{array}$ & South India & Asia & $33 / 112$ & $29.46(21.23-38.82)$ & & & 20 & 13 \\
\hline Bin Lu et al. 2013 [28] & China & Asia & $45 / 534$ & $8.43(6.21-11.11)$ & 230 & 304 & 13 & 32 \\
\hline Charles et al. 2011 [29] & Denmark & Europe & $329 / 507$ & $64.89(60.56-69.05)$ & & & & \\
\hline Codogno et al. 2011 [30] & Brazil & America & $32 / 121$ & $26.45(18.84-35.24)$ & 72 & 49 & 23 & 9 \\
\hline Delcourt et al. 1996 [31] & France & Europe & $136 / 427$ & $31.85(27.45-36.50)$ & & & & \\
\hline Hamdan et al. 2012 [32] & USA & America & $29 / 100$ & $29.00(20.36-38.93)$ & 59 & 41 & & \\
\hline
\end{tabular}




\begin{tabular}{|c|c|c|c|c|c|c|c|c|}
\hline Author & Country & Continent & $\begin{array}{l}\text { Patients } \\
\text { with DPN/ } \\
\text { T2DM }\end{array}$ & $\begin{array}{c}\text { Prevalence (T2DM) } \\
\%(95 \% \mathrm{Cl})\end{array}$ & \begin{tabular}{|c|} 
Men \\
with \\
T2DM
\end{tabular} & $\begin{array}{c}\text { Women } \\
\text { with } \\
\text { T2DM }\end{array}$ & $\begin{array}{l}\text { Men } \\
\text { with } \\
\text { DPN }\end{array}$ & $\begin{array}{c}\text { Women } \\
\text { with } \\
\text { DPN }\end{array}$ \\
\hline Hanley et al. 2004 [33] & Canada & America & $147 / 318$ & $46.23(40.65-51.88)$ & 111 & 207 & & \\
\hline Jang et al. 2013 [34] & Korea & Asia & $64 / 175$ & 36.57 (29.43-44.17) & & & & \\
\hline $\begin{array}{l}\text { Janghorbani et al. } 2006 \\
\text { [35] }\end{array}$ & Iran & Asia & $608 / 810$ & 75.06 (71.93-78.01) & 289 & 521 & 216 & 392 \\
\hline $\begin{array}{l}\text { Jarmuzewska and } \\
\text { Mangoni } 2005 \text { [36] }\end{array}$ & Australia & Oceania & $28 / 55$ & 50.91 (37.07-64.65) & & & & \\
\hline Jianbo et al. 2011 [37] & China & Asia & $80 / 227$ & 35.24 (29.04-41.84) & & & & \\
\hline Kamenov et al. 2010 [38] & Bulgaria & Europe & $1344 / 1705$ & 78.83 (76.81-80.74) & 744 & 961 & 585 & 759 \\
\hline $\begin{array}{l}\text { Kastenbauer et al. } 2003 \\
\text { [39] }\end{array}$ & Austria & Europe & $96 / 256$ & 37.50 (31.55-43.74) & 130 & 126 & & \\
\hline Kiani et al. 2013 [40] & Iran & Asia & $264 / 521$ & $50.67(46.29-55.05)$ & & & & \\
\hline Liang et al. 2005 [41] & Japan & Asia & $35 / 166$ & 21.08 (15.15-28.08) & & & & \\
\hline Liu et al. 2010 [42] & China & Asia & $117 / 1193$ & $9.81(8.18-11.64)$ & 594 & 599 & & \\
\hline Paisey et al. 1984 [43] & Mexico & America & $205 / 503$ & $40.76(36.43-45.19)$ & 199 & 304 & 89 & 116 \\
\hline $\begin{array}{l}\text { Pop-Busui et al. } 2009 \\
\text { [44] }\end{array}$ & USA & America & $1173 / 2314$ & $50.46(48.43-52.50)$ & 1681 & 687 & 642 & 553 \\
\hline $\begin{array}{l}\text { Pradeepa et al. } 2008 \\
\text { [45] }\end{array}$ & India & Asia & $425 / 1629$ & 26.09 (23.97-28.29) & & & 195 & 230 \\
\hline Shaw et al. 1998 [46] & Australia & Oceania & $70 / 847$ & $8.26(6.50-10.33)$ & 387 & 460 & 45 & 25 \\
\hline Sloten et al. 2011 [47] & Netherlands & Europe & $40 / 100$ & $40.00(30.33-50.28)$ & 69 & 31 & & \\
\hline Tahrani et al.2012 [48] & $\begin{array}{l}\text { United } \\
\text { Kingdom }\end{array}$ & Europe & $112 / 234$ & 47.86 (41.31-54.47) & 136 & 98 & & \\
\hline Voulgari et al. 2011 [49] & Greece & Europe & $122 / 400$ & $30.50(26.02-35.27)$ & 178 & 222 & & \\
\hline Wang et al. 2011 [50] & USA & America & $78 / 816$ & $9.56(7.63-11.79)$ & 369 & 447 & 37 & 41 \\
\hline \multirow[t]{2}{*}{ Total } & & & $6746 / 16337$ & 35.37 (27.77-43.80) & 6160 & 5989 & 1865 & 2170 \\
\hline & \multicolumn{8}{|c|}{$\mathrm{Cl}=$ Confidence Interval; DPN = Diabetic Peripheral Neuropathy; T2DM = Type 2 Diabetes Mellitus } \\
\hline
\end{tabular}

$11.11 \%$ ) to $78.83 \%$ (95\% Cl: $76.81 \%-80.74 \%$ ) (Figure 2). The heterogeneity among the studies was high $\left(I^{2}=99.0 \% ; \tau^{2}=0.9236 ; p<0.0001\right)$.

In the sensitivity analysis per continent, the prevalence of DPN was higher in Europe (48.14\%; 95\% $\mathrm{Cl}$ : 33.31-63.30\%) than in the Americas (31.61\%; 95\% Cl: 18.93-47.78\%), Asia (32.24\%; 95\% Cl: 20.53-46.69\%), and Oceania (23.20\%; 95\% Cl: 2.68-76.80\%) (Figure 3).

The average age of the participants with type 2 DM was calculated in 22 studies and was found to range from $46.5 \pm 13.3$ to $64.0 \pm 11.6$ years old . The average age of the participants with DPN was included in 10 studies and varied from $53.8 \pm 9.8$ to $69.6 \pm 9.5$ years old (Table 2 ). The distribution of the participants with type 2 DM by gender did not indicate any differences (women, $n=5,989$; men, $n=6,160)$. These characteristics are described in Table 1.

The sources of heterogeneity among the studies were investigated by a meta-regression analysis that included clinical cofactors such as year, duration of DM, average duration of DPN, and average HbA1c level. However, the results did not indicate any cofactors as a cause of the heterogeneity (Figure 4) 
Figure 2: Prevalence of Diabetic Peripheral Neuropathy in Type 2 Diabetes Mellitus patients.

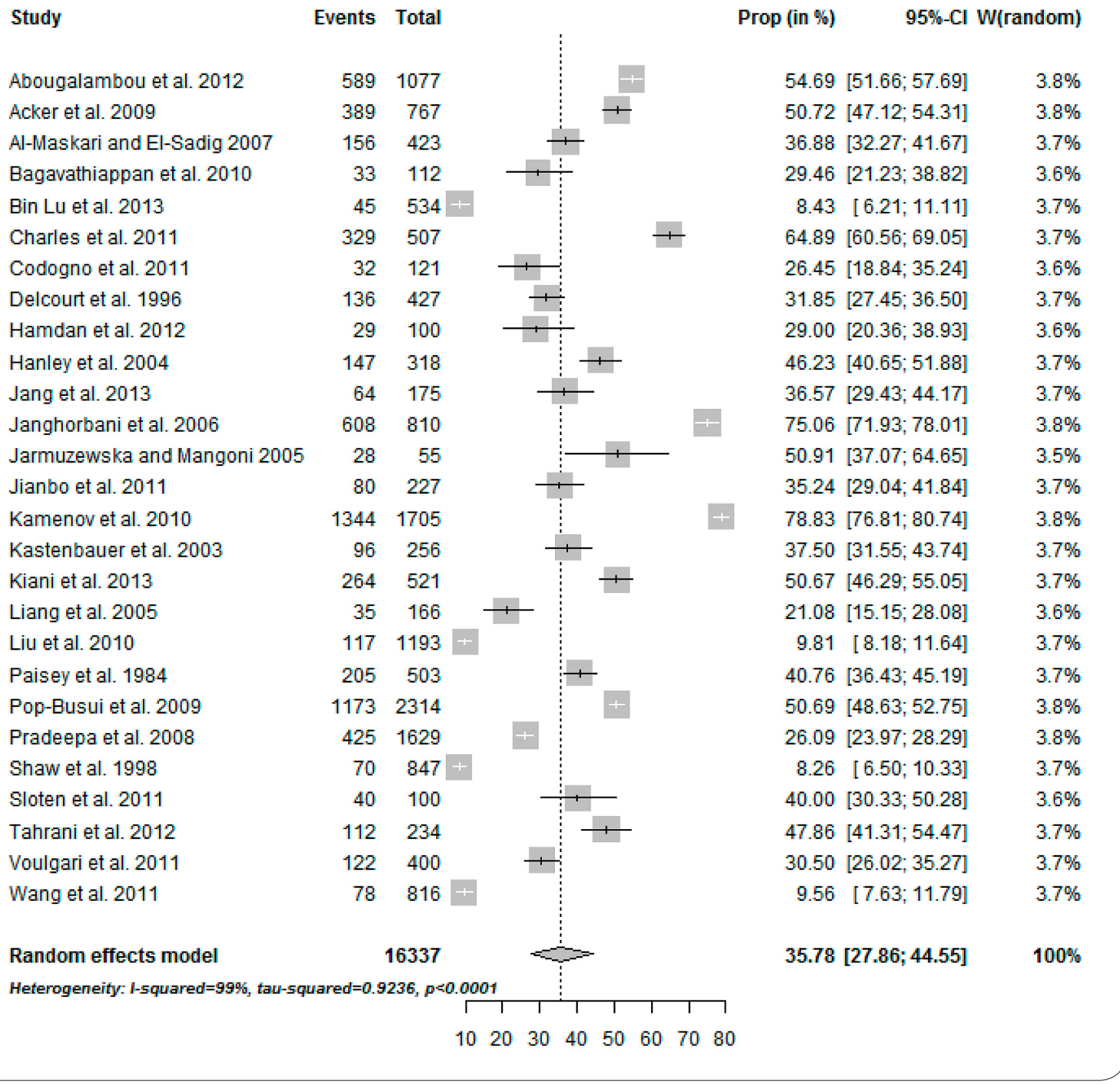

The analysis of the publication bias for the 27 studies included in the meta-analysis is depicted in the funnel plot presented in Figure 5. In the plot, which represents the prevalence of cases, the $x$ axis corresponds to the logit of prevalence, and the $y$-axis corresponds to the standard error of the studies. The almost symmetric distribution of the points is suggestive of the absence of publication bias, which was confirmed by the result of the Begg test $(p=0.0764)$. 
Figure 3. Prevalence of diabetic peripheral neuropathy in type 2 diabetes mellitus patients by continent.

Study

Continent: $=$ America

Codogno et al. 2011

Hamdan et al. 2012

Hanley et al. 2004

Paisey et al. 1984

Pop-Busui et al. 2009

Wang et al. 2011

Random effects model

Heterogeneity: 1 -squared=98.69\%, tau-Equared $=0.7073, p \leq 0.0001$

Continent: $=$ Asia

Abougalambou et al. 2012

Al-Maskari and El-Sadig 2007

Bagavathiappan et al. 2010

Bin Lu et al. 2013

Jang et al. 2013

Janghorbani et al. 2006

Jianbo et al. 2011

Kiani et al. 2013

Liang et al. 2005

Liu et al. 2010

Pradeepa et al. 2008

Random effects model

Heterogeneity: $1-$ squared $=99.1 \%$, tau-squared $=1.05, p \leqslant 0.0001$

Continent: $=$ Europe

Acker et al. 2009

Charles et al. 2011

Delcourt et al. 1996

Kamenov et al. 2010

Kastenbauer et al. 2003

Sloten et al. 2011

Tahrani et al. 2012

Voulgari et al. 2011

Random effects model

Heterogeneity: 1 -squared $=98.9 \%$, tau-squared $=0.7851, p \leq 0.0001$

Continent $=$ Oceania

Jarmuzewska and Mangoni 2005

Shaw et al. 1998

Random effects model

Heterogeneity: $1-$ squared $=98.5 \%$, tau-squared $=2.941, p<0.0001$

\section{0}

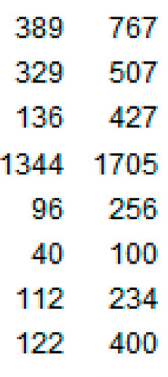

67

\section{7}

\section{5}

56

00

34

4396

Random effects model

16337

Heterogeneity: 1 -squared $=99 \%$, tau-squared $=0.9236$, $p<0.0001$

$\begin{array}{llllllll}10 & 20 & 30 & 40 & 50 & 60 & 70 & 80\end{array}$
Prop (in \%) $\quad 95 \%-\mathrm{Cl}$ W(random)

$\begin{array}{rr}26.45[18.84 ; 35.24] & 3.6 \% \\ 29.00[20.36 ; 38.93] & 3.6 \% \\ 46.23[40.65 ; 51.88] & 3.7 \% \\ 40.76[36.43 ; 45.19] & 3.7 \% \\ 50.69[48.63 ; 52.75] & 3.8 \% \\ 9.56[7.63 ; 11.79] & 3.7 \% \\ 31.61[18.93 ; 47.78] & 22.2 \%\end{array}$

$54.69[51.66 ; 57.69] \quad 3.8 \%$

$36.88[32.27 ; 41.67] \quad 3.7 \%$

$29.46[21.23 ; 38.82] \quad 3.6 \%$

$8.43 \quad[6.21 ; 11.11] \quad 3.7 \%$

$36.57[29.43 ; 44.17] \quad 3.7 \%$

$75.06[71.93 ; 78.01] \quad 3.8 \%$

$35.24[29.04 ; 41.84] \quad 3.7 \%$

$50.67[46.29 ; 55.05] \quad 3.7 \%$

$21.08[15.15 ; 28.08] \quad 3.6 \%$

$9.81[8.18 ; 11.64] \quad 3.7 \%$

$26.09[23.97 ; 28.29] \quad 3.8 \%$

$32.24[20.53 ; 46.69] \quad 40.8 \%$

$50.72[47.12 ; 54.31] \quad 3.8 \%$

$64.89[60.56 ; 69.05] \quad 3.7 \%$

$31.85[27.45 ; 36.50] \quad 3.7 \%$

$78.83[76.81 ; 80.74] \quad 3.8 \%$

$37.50[31.55 ; 43.74] \quad 3.7 \%$

$40.00[30.33 ; 50.28] \quad 3.6 \%$

$47.86[41.31 ; 54.47] \quad 3.7 \%$

$30.50[26.02 ; 35.27] \quad 3.7 \%$

$48.14[33.31 ; 63.30] \quad 29.8 \%$

$50.91[37.07 ; 64.65] \quad 3.5 \%$

$8.26[6.50 ; 10.33] \quad 3.7 \%$

$23.20[2.68 ; 76.80] \quad 7.2 \%$

$35.78[27.86 ; 44.55] \quad 100 \%$ 
Table 2. Features of the studies included in the meta-analysis.

\begin{tabular}{|c|c|c|c|c|c|c|}
\hline Author & $\begin{array}{c}\text { Mean age ( } \pm \text { SD or } 95 \% \\
\mathrm{CI} \text { ) or age group in } \\
\text { patients with T2DM } \\
\text { (years) }\end{array}$ & $\begin{array}{c}\text { Mean age ( } \pm \text { SD or } \\
95 \% \mathrm{CI} \text { ) or age group } \\
\text { in patients with DPN } \\
\text { (years) }\end{array}$ & $\begin{array}{c}\text { Duration of } \\
\text { diabetes } \\
\text { (years) }\end{array}$ & $\begin{array}{c}\text { Duration of } \\
\text { DPN } \\
\text { (years) }\end{array}$ & $\begin{array}{c}\text { Glycated hemoglobin } \\
\text { level in patients with } \\
\text { T2DM } \\
\text { (mean } \pm \text { SD or } 95 \% \mathrm{CI} \text { ) }\end{array}$ & $\begin{array}{l}\text { Glycated hemoglobin } \\
\text { level in patients with } \\
\text { DPN } \\
\text { (mean } \pm \text { SD or } 95 \% \mathrm{CI} \text { ) }\end{array}$ \\
\hline Acker et al. 2009 [25] & $63.6 \pm 11.0$ & & $11(6-18)$ & & $7.58 \pm 1.29$ & \\
\hline Al-Maskari and El-Sadig 2007 [26] & $53.0 \pm 13.0$ & & & & & \\
\hline Bagavathiappan et al. 2010 [27] & & $62.3 \pm 12.0$ & & $15.2 \pm 10.1$ & & $8.6 \pm 2.4$ \\
\hline Bin Lu et al. 2013 [28] & $64.0 \pm 9.9$ & $69.6 \pm 9.5$ & & & & \\
\hline Charles et al. 2011 [29] & $40-69$ & & & & & \\
\hline Codogno et al. 2011 [30] & $60.1 \pm 8.9$ & & & & & \\
\hline Delcourt et al. 1996 [31] & $35-74$ & & & & & \\
\hline Hamdan et al. 2012 [32] & $53.46 \pm 9.51$ & & & & & \\
\hline Hanley et al. 2004 [33] & $46.5 \pm 13.3$ & & $9.0(3-11)$ & & & \\
\hline Janghorbani et al. 2006 [35] & $52.7 \pm 9.9$ & $53.8 \pm 9.8$ & $8.2 \pm 6.8$ & $9.1 \pm 6.9$ & $11.0 \pm 2.4$ & \\
\hline Jarmuzewska and Mangoni 2005 [36] & $62.6 \pm 8.0$ & $64.9 \pm 8.2$ & $13.0 \pm 9.6$ & $16.3 \pm 10.8$ & $5.7 \pm 1.0$ & $5.8 \pm 1.2$ \\
\hline Jianbo et al. 2011 [37] & $40-70$ & $65.5(59.0-70.9)$ & & $13.3(10.2-20.5)$ & & $9.0 \pm 3.1$ \\
\hline Kamenov et al. 2010 [38] & $60.0 \pm 11.9$ & $\begin{array}{c}\text { men } 63 \text { (56-70), } \\
\text { women } 60 \text { (51-67) }\end{array}$ & $\begin{array}{c}\text { men } 6(1-12) \\
\text { women 8(4-13) }\end{array}$ & $\begin{array}{c}\text { men 9(3-15) } \\
\text { women 10(5-16) }\end{array}$ & $\begin{array}{c}\text { men } 8.7(7.5-10.5) \\
\text { women } 8.7(7.5-10.1)\end{array}$ & $\begin{array}{c}\text { men } 8.6 \text { (7.5-10.4), } \\
\text { women } 8.7(7.5-10.1)\end{array}$ \\
\hline Kastenbauer et al. 2003 [39] & $64.0 \pm 11.6$ & & $10.3 \pm 8.3$ & & $7.9 \pm 1.3$ & \\
\hline Kiani et al. 2013 [40] & $57.0 \pm 10.6$ & $59.3 \pm 11.6$ & $9.2 \pm 7.4$ & $11.4 \pm 8.0$ & & \\
\hline Liang et al. 2005 [41] & $35-74$ & $54(44-62)$ & & $6(2-14)$ & & \\
\hline Liu et al. 2010 [42] & $59.17 \pm 11.82$ & & $6.45 \pm 6.32$ & & $7.41 \pm 1.86$ & \\
\hline Paisey et al. 1984 [43] & & & 13.7 & & & \\
\hline
\end{tabular}




\begin{tabular}{|c|c|c|c|c|c|c|}
\hline Author & $\begin{array}{l}\text { Mean age } \\
( \pm \text { SD or } 95 \% \\
\text { CI) or age } \\
\text { group in } \\
\text { patients with } \\
\text { T2DM (years) }\end{array}$ & $\begin{array}{l}\text { Mean age } \\
\text { ( } \pm \text { SD or } 95 \% \\
\text { CI) or age } \\
\text { group in } \\
\text { patients with } \\
\text { DPN (years) }\end{array}$ & $\begin{array}{c}\text { Duration } \\
\text { of } \\
\text { diabetes } \\
\text { (years) }\end{array}$ & $\begin{array}{c}\text { Duration } \\
\text { of } \\
\text { DPN } \\
\text { (years) }\end{array}$ & $\begin{array}{c}\text { Glycated } \\
\text { hemoglobin } \\
\text { level in patients } \\
\text { with T2DM } \\
\text { (mean } \pm \text { SD or } \\
95 \% \mathrm{Cl})\end{array}$ & $\begin{array}{c}\text { Glycated } \\
\text { hemoglobin } \\
\text { level in patients } \\
\text { with DPN } \\
\text { (mean } \pm \text { SD or } \\
95 \% \mathrm{Cl} \text { ) }\end{array}$ \\
\hline Pop-Busui et al. 2009 [44] & $62.4 \pm 8.9$ & & $10.4 \pm 8.7$ & & $7.7 \pm 1.6$ & \\
\hline R. Pradeepa et al. 2008 [45] & & $60.0 \pm 9.0$ & & $6.7 \pm 6.7$ & & $9.0 \pm 2.3$ \\
\hline Shaw et al. 1998 [46] & & $56.0 \pm 11.0$ & & $5(1-11)$ & & \\
\hline Sloten et al. 2011 [47] & $64.5 \pm 9.4$ & & $4.0(2.0-7.0)$ & & $6.8 \pm 0.8$ & \\
\hline \multicolumn{7}{|l|}{ Tahrani et al.2012 [48] } \\
\hline Voulgari et al. 2011 [49] & $58.7 \pm 10.1$ & & $7.0(3.0-41.0)$ & & $9.17 \pm 3.41$ & \\
\hline Wang et al. 2011 [50] & $57.0 \pm 14.0$ & & & & & \\
\hline
\end{tabular}

Figure 4: Meta-regression: bubble plot of duration of diabetes in years (a), duration of diabetic peripheral neuropathy in years (b), average glycated hemoglobin level (c), and publication year (d); and Q-Q norm plot of duration of diabetes in years (e), duration of diabetic peripheral neuropathy in years $(\mathrm{f})$, average glycated hemoglobin level (g), and publication year (h).
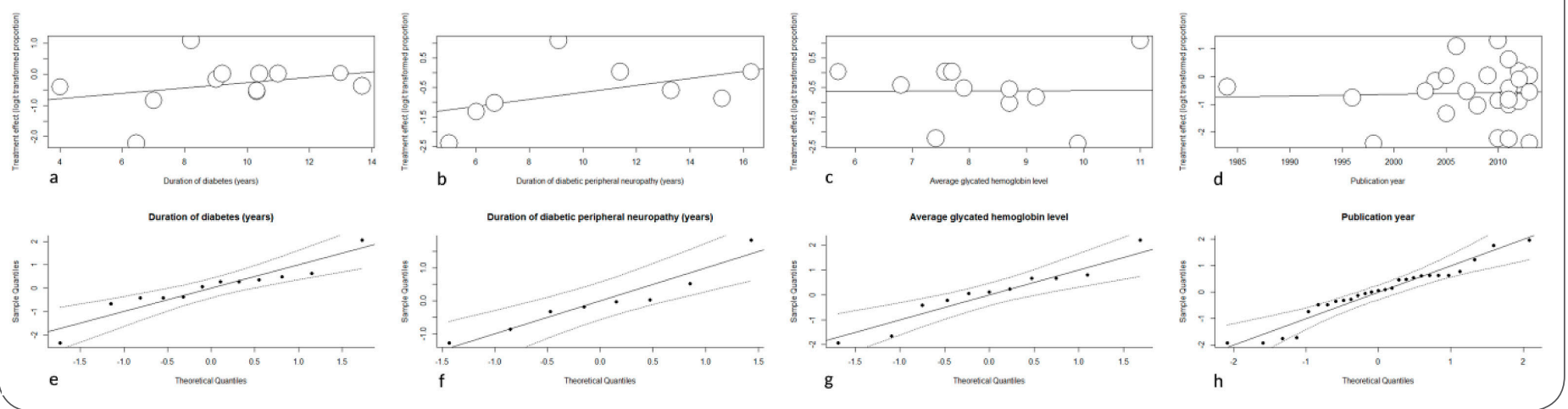

Figure 5: Funnel plot for the estimation of publication bias.

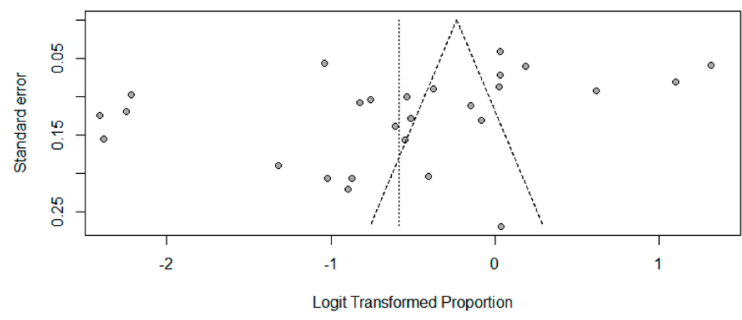

\section{Discussion}

DPN is defined as a neurological disorder caused by progressive loss of the motor, sensory, and autonomic functions of the nerve fibers, which affects the main divisions of the peripheral nervous system in patients with DM [51].

When associated with DM, chronic peripheral neuropathy is a progressive and insidious pathological process. Its severity is associated not only with the signs and symptoms exhibited by patients but also with the fact that it represents the beginning of a pathophysiological process that leads to ulceration and amputation when it is not controlled early in its course [52-54]. 
The signs and symptoms of sensory-motor neuropathies vary according to the type of nerve fibers that are affected. Damage to the thick fibers might cause reduction of the sensitivity to touch and vibration and decreased sensitivity of proprioception. In turn, damage to the thin fibers causes changes in the sensitivity to pain, temperature, and affective touch. Other associated symptoms include neuropathic pain and paresthesia. In general, both the thick and thin fibers are affected by the neuropathic process; the motor symptoms become more common as the disease progresses [55].

We did not include the prevalence of DPN by gender in the meta-analysis because only a few studies have investigated the occurrence of this condition in men and women separately. However, it is worth noting that in the studies in which this information was available, no gender differences in the predominance of DPN were detected (women, $n=2,170$; men, $n=1,865)$. This finding is consistent with reports in the literature indicating that the development of DPN does not differ between genders. Previouly studies showed no clear association to gender [56]. However, it has been suggested previously that ethnicity may affect the development of neuropathy [57].

The average ages of the individuals with type 2 DM varied from $46.5 \pm 13.3$ to $64.0 \pm 9.5$ years old, and the average ages of patients with DPN from varied from $53.8 \pm 9.8$ to $69.6 \pm 9.5$ years old Older age, having diabetes for 10 years or more, and inadequate glycemic control are well-known risk factors for DPN. In addition, smoking, retinopathy, hypertension, obesity, hyperlipidemia, and microalbuminuria have been described as possible risk markers [58].

Several studies have described a longer duration of diabetes as a risk factor for DPN [59-62]. However, the association between diabetes duration and prevalence of DPN might partially depend on the patient's age, which is a risk factor by itself [63]. Our meta-analysis investigated the association between diabetes duration, age and prevalence of DPN, however, we find no statistically significant of this association.

Our analysis revealed high heterogeneity among the studies $\left(I^{2}=99.0 \% ; \tau^{2}=0.9236 ; p<0.0001\right)$. To investigate this heterogeneity more thoroughly, sensitivity and meta-regression analyses were performed.

Our results showed that the prevalence of DPN was higher in Europe [48.14\%, 95\% Cl: 33.31\%$63.30 \%)$ than in the Americas $(31.61 \%, 95 \% \mathrm{Cl}$ : 18.93\%-47.78\%), Asia (32.24\%, 95\% Cl: 20.53\%$46.69 \%)$, and Oceania $(23.20 \%, 95 \% \mathrm{Cl}: 2.68 \%-$ $76.80 \%)$. This distribution is different from that of DM prevalence, which is lower in Europe (7.9\%) than the global average (8.3\%). In the remaining continents, the prevalence of DM is $11.4 \%$ in North America, 8.1\% in South America, 8.3\% in Asia, and $8.5 \%$ in Oceania. It should be noted that the global prevalence of DM is not uniform, with $77 \%$ of the affected population living in low- and middleincome countries [1].

Regional characteristics and potential risk factors may have influenced the differences presented, as glycemic control, age, height and duration of T2DM. For every 10 years of T2DM, duration of the risk of DPN increases 73\%[64]. The prevalence of DPN, ulcers and amputations is lower among Asian and african-Caribbean compared with European [65], can the person's height explain the DPN be more common among men: longer axons are more exposed to damage [66]. Other modifiable risk factors are metabolic syndrome and its components, such as smoking, also are associated with T2DM [67].

The diagnostic methods used differed among studies due to differences in the study aims. Rather than selecting a diagnostic method based on its efficacy alone, one should also consider the possibility of applying a method specific for the target population. For example, the consensus statement published in January 2012 by the American Diabetes Association attributes a particular value to the entire 
scope of clinical aspects (clinical signs and symptoms) as a standard protocol for the screening of DPN instead of using quantitative laboratory tests. The latter are not mandatory due to their restricted availability resulting from their high cost and complexity. In addition, the published studies had small, non-representative samples or even biased designs [68].

However, previously published and ongoing studies describe promising diagnostic methods for DPN, allowing for earlier diagnosis than that based on the clinical signs and symptoms. These methods, particularly the neurophysiological tests, are reproducible and less subjective than the clinical methods [68].

The main tests used for the diagnosis of DPN in the studies included in the meta-analysis were the Neuropathy Disability Score (NDS), Neuropathy Symptom Score (NSS), Michigan Neuropathy Screening Instrument (MNSI), $10 \mathrm{~g}$ Semmes-Weinstein Monofilament Examination (SWME), and quantitative sensory testing by the vibration perception threshold (VPT), usually combined with clinical assessment and/or electromyography. These tests are useful for evaluating DPN in research and in the clinic, showing similarities and differences between them. The most of diagnosed neuropathies with these tools are related to T2DM and the reason of high prevalence of DPN in adult with T2DM and more ability of these three tools for large fiber neuropathy screening [69-71].

Regarding the accuracy of the tests, the NDS, NSS, and VTP exhibited $92.31 \%, 82.05 \%$, and $86.00 \%$ sensitivity and $47.62 \%, 66.67 \%$, and $76.00 \%$ specificity, respectively. For the MNSI score cutoff points of $1.5,2.0,2.5$, and 3.0, the test exhibits $79 \%$, $65 \%, 50 \%$, and $35 \%$ sensitivity and 65\%, 83\%, $91 \%$, and $94 \%$ of specificity, respectively [12].

The accuracy of the SWME was assessed in a systematic review conducted in 2009, which found that its sensitivity ranged from $41 \%$ to $93 \%$, and its specificity ranged from $68 \%$ to $100 \%$ [11].
The evidence regarding the ideal screening method for DPN is currently limited. Nevertheless, many advances have been made for the detection of DPN regarding the results of tests, electrophysiological techniques, and quantitative sensory tests [13].

In our meta-analysis, the global prevalence of DPN among individuals with type 2 DM was 35.78\% (95\% Cl: $27.86-44.55 \%)$. According to data in the literature, DPN is the most common long-term complication of diabetes, affecting approximately $50 \%$ of patients with type 2 DM (ranging from 30\% to $90 \%$ ). In addition, DPN is characterized as a factor that contributes the most to weakening of patients $[8,63,68,70,72]$.

\section{Conclusion}

The data collected in the present study suggest that the prevalence of DPN among individuals with type $2 \mathrm{DM}$ is high. For that reason, and given the impact of the complications of DPN on the quality of life of the affected patients and the cost of care for these complications, this condition should be considered a significant public health problem.

We recommend interpreting the data reported here cautiously due to the high heterogeneity found among the studies.

\section{References}

1. IFD. International Diabetes Federation: IDF.org; 2015. Available from: http://www.idf.org/

2. Bansal D, Gudala K, Muthyala H, Esam HP, Nayakallu R, Bhansali A. Prevalence and risk factors of development of peripheral diabetic neuropathy in type 2 diabetes mellitus in a tertiary care setting. J diabetes investig. 2014; 5(6):714-21.

3. Boulton AJM, Vinik Al, Arezzo JC, Bril V, Feldman EL, Freeman $\mathrm{R}$, et al. Diabetic neuropathies a statement by the American Diabetes Association. Diabetes care. 2005; 28(4):956-62.

4. Vinik Al, Maser RE, Mitchell BD, Freeman R. Diabetic autonomic neuropathy. Diabetes care. 2003; 26(5):1553-79.

5. Sandireddy R, Yerra VG, Areti A, Komirishetty P, Kumar A. Neuroinflammation and oxidative stress in diabetic neuropathy: futuristic strategies based on these targets. Int $j$ endocrinol. 2014; 2014:10 
6. Katsuda Y, Sasase T, Tadaki H, Mera Y, Motohashi Y, Kemmochi $Y$, et al. Contribution of hyperglycemia on diabetic complications in obese type 2 diabetic SDT fatty rats: effects of SGLT inhibitor phlorizin. Exp anim. 2015; 64(2):161-9

7. Xu F, Zhao LH, Su JB, Chen T, Wang XQ, Chen JF, et al. The relationship between glycemic variability and diabetic peripheral neuropathy in type 2 diabetes with well-controlled HbA1c. Diabetol metab syndr. 2014; 6(1):139.

8. Wu J, Zhang X, Zhang B. Efficacy and safety of puerarin injection in treatment of diabetic peripheral neuropathy: a systematic review and meta-analysis of randomized controlled trials. J tradit chin med. 2014; 34(4):401-10.

9. Asad A, Hameed MA, Khan UA, Ahmed N, Butt MU. Reliability of the neurological scores for assessment of sensorimotor neuropathy in type 2 diabetics. J pak med assoc. 2010; 60(3):166-70.

10. Caiafa JS, Castro AA, Fidelis C, Santos VP, Silva ES, Sitrângulo CJJ. Atenção integral ao portador de pé diabético. J vasc bras. 2011; 10:1-32

11. Dros J, Wewerinke A, Bindels PJ, Weert HC. Accuracy of monofilament testing to diagnose peripheral neuropathy: a systematic review. Ann fam med. 2009; 7(6):555-8.

12. Moghtaderi A, Bakhshipour A, Rashidi H. Validation of Michigan neuropathy screening instrument for diabetic peripheral neuropathy. Clin neurol neurosurg. 2006; 108(5):477-81.

13. Mythili A, Kumar KD, Subrahmanyam KAV, Venkateswarlu K, Butchi RG. A Comparative study of examination scores and quantitative sensory testing in diagnosis of diabetic polyneuropathy. Int j diabetes dev ctries. 2010; 30(1):43-8.

14. Deeks J, Bossuyt P, Gatsonis C. Cochrane handbook for systematic reviews of diagnostic test accuracy version 1.0. 0 The Cochrane Collaboration. Cochrane database syst rev. 2009.

15. Egger M, Smith GD, Altman D. Systematic reviews in health care: meta-analysis in context: John Wiley \& Sons; 2008.

16. Higgins JP, Thompson SG, Deeks JJ, Altman DG. Measuring inconsistency in meta-analyses. BMJ. 2003; 327(7414):557-60.

17. Huedo-Medina TB, Sanchez-Meca J, Marin-Martinez F, Botella J. Assessing heterogeneity in meta-analysis: Q statistic or 12 index? Psychol methods. 2006; 11(2):193-206.

18. Stanley TD, Doucouliagos H. Meta-regression approximations to reduce publication selection bias. Res synth methods. 2014; 5(1):60-78

19. Begg CB, Mazumdar M. Operating characteristics of a rank correlation test for publication bias. Biometrics. 1994; 50(4):1088-101.

20. Sterne JA, Egger M. Funnel plots for detecting bias in metaanalysis: guidelines on choice of axis. J clin epidemiol. 2001; 54(10):1046-55

21. Langan D, Higgins JP, Gregory W, Sutton AJ. Graphical augmentations to the funnel plot assess the impact of additional evidence on a meta-analysis. J clin epidemiol. 2012; 65(5):511-9.

22. Sterne JA, Sutton AJ, Ioannidis JP, Terrin N, Jones DR, Lau J, et al. Recommendations for examining and interpreting funnel plot asymmetry in meta-analyses of randomised controlled trials. BMJ. 2011; 343:d4002.
23. Whiting PF, Sterne JA, Westwood ME, Bachmann LM, Harbord $R$, Egger $M$, et al. Graphical presentation of diagnostic information. BMC med res methodol. 2008; 8:20.

24. Abougalambou SS, Abougalambou AS. Explorative study on diabetes neuropathy among type II diabetic patients in Universiti Sains Malaysia Hospital. Diabetes metab syndr. 2012; 6(3):16772 .

25. Acker K, Bouhassira D, Bacquer D, Weiss S, Matthys K, Raemen $\mathrm{H}$, et al. Prevalence and impact on quality of life of peripheral neuropathy with or without neuropathic pain in type 1 and type 2 diabetic patients attending hospital outpatients clinics. Diabetes metab. 2009; 35(3):206-13.

26. Al-Maskari F, El-Sadig M. Prevalence of risk factors for diabetic foot complications. BMC fam pract. 2007; 8:59.

27. Bagavathiappan S, Philip J, Jayakumar T, Raj B, Rao PN, Varalakshmi $M$, et al. Correlation between plantar foot temperature and diabetic neuropathy: a case study by using an infrared thermal imaging technique. J diabetes sci technol. 2010; 4(6):1386-92.

28. Bin-Lu, Hu J, Wen J, Zhang Z, Zhou L, Li Y, et al. Determination of Peripheral Neuropathy Prevalence and Associated Factors in Chinese Subjects with Diabetes and Pre-Diabetes - ShangHai Diabetic neuRopathy Epidemiology and Molecular Genetics Study (SHDREAMS). Plos one. 2013; 8(4):e61053.

29. Charles M, Ejskjaer N, Witte DR, Borch-Johnsen K, Lauritzen T, Sandbaek A. Prevalence of neuropathy and peripheral arterial disease and the impact of treatment in people with screendetected type 2 diabetes: the ADDITION-Denmark study. Diabetes care. 2011; 34(10):2244-9.

30. Codogno JS, Fernandes RA, Sarti FM, Freitas Junior IF, Monteiro $\mathrm{HL}$. The burden of physical activity on type 2 diabetes public healthcare expenditures among adults: a retrospective study. BMC public health. 2011; 11:275.

31. Delcourt C, Cathelineau BV, Kervroedan FV, Papoz L. Clinical correlates of advanced retinopathy in type II diabetic patients: implications for screening. The CODIAB-INSERM-Zeneca Pharma Study Group. J clin epidemiol. 1996; 49(6):679-85.

32. Hamdan AL, Jabbour J, Barazi R, Korban Z, Azar ST. Prevalence of laryngopharyngeal reflux disease in patients with diabetes mellitus. J voice. 2013; 27(4):495-9.

33. Hanley AJ, Harris SB, Mamakeesick M, Goodwin K, Fiddler E, Hegele RA, et al. Complications of Type 2 Diabetes Among Aboriginal Canadians: prevalence and associated risk factors. Diabetes care. 2005; 28(8):2054-7.

34. Jang EH, Park YM, Hur J, Kim MK, Ko SH, Baek KH, et al. Higher levels of small dense low-density lipoprotein (LDL) are associated with cardiac autonomic neuropathy in patients with type 2 diabetes. Diabet med. 2013; 30(6):694-701.

35. Janghorbani M, Rezvanian $H$, Kachooei A, Ghorbani A, Chitsaz A, Izadi F, et al. Peripheral neuropathy in type 2 diabetes mellitus in Isfahan, Iran: prevalence and risk factors. Acta neurol scand. 2006; 114(6):384-91.

36. Jarmuzewska EA, Mangoni AA. Pulse pressure is independently associated with sensorimotor peripheral neuropathy in patients with type 2 diabetes. J intern med. 2005; 258(1):38-44 
37. Jianbo L, Yuche $C$, Ming $S$, Jingrong $T$, Qing $D, Y u Z$, et al. Association of homocysteine with peripheral neuropathy in Chinese patients with type 2 diabetes. Diabetes res clin pract. 2011; 93(1):38-42.

38. Kamenov ZA, Parapunova RA, Georgieva RT. Earlier development of diabetic neuropathy in men than in women with type 2 diabetes mellitus. Gend med. 2010; 7(6):600-15.

39. Kastenbauer T, Irsigler P, Sauseng S, Grimm A, Prager R. The prevalence of symptoms of sensorimotor and autonomic neuropathy in Type 1 and Type 2 diabetic subjects. J diabetes complications. 2003; 18(1):27-31.

40. Kiani J, Moghimbeigi A, Azizkhani H, Kosarifard S. The prevalence and associated risk factors of peripheral diabetic neuropathy in Hamedan, Iran. Arch iran med. 2013; 16(1):17-9.

41. Liang $H$, Murase $Y$, Katuta $Y$, Asano A, Kobayashi J, Mabuchi H. Association of LMNA 1908C/T polymorphism with cerebral vascular disease and diabetic nephropathy in Japanese men with type 2 diabetes. Clin endocrinol. 2005; 63(3):317-22.

42. Liu F, Bao Y, Hu R, Zhang $X$, Li H, Zhu D, et al. Screening and prevalence of peripheral neuropathy in type 2 diabetic outpatients: a randomized multicentre survey in 12 city hospitals of China. Diabetes metab res rev. 2010; 26(6):481-9.

43. Paisey RB, Arredondo G, Villalobos A, Lozano O, Guevara L, Kelly S. Association of differing dietary, metabolic, and clinical risk factors with microvascular complications of diabetes: a prevalence study of 503 Mexican type II diabetic subjects II. Diabetes care. 1984; 7(5):428-33.

44. Pop-Busui R, Lu J, Lopes N, Jones TL, Investigators BD. Prevalence of diabetic peripheral neuropathy and relation to glycemic control therapies at baseline in the BARI 2D cohort. J peripher nerv syst. 2009; 14(1):1-13.

45. Pradeepa R, Rema M, Vignesh J, Deepa M, Deepa R, Mohan V. Prevalence and risk factors for diabetic neuropathy in an urban south Indian population: the Chennai Urban Rural Epidemiology Study (CURES-55). Diabet med. 2008; 25(4):407-12.

46. Shaw JE, Hodge AM, Courten M, Dowse GK, Gareeboo H, Tuomilehto J, et al. Diabetic neuropathy in Mauritius: prevalence and risk factors. Diabetes res clin pract. 1998; 42(2):131-9.

47. Sloten TTV, Savelberg HH, Peeters IGD, Meijer K, Henry RM, Stehouwer CD, et al. Peripheral neuropathy, decreased muscle strength and obesity are strongly associated with walking in persons with type 2 diabetes without manifest mobility limitations. Diabetes res clin pract. 2011; 91(1):32-9.

48. Tahrani AA, Ali A, Raymond NT, Begum S, Dubb S, Mughal $S$, et al. Obstructive sleep apnea and diabetic neuropathy: a novel association in patients with type 2 diabetes. Am j pespir crit care med. 2012; 186(5):434-41.

49. Voulgari C, Psallas M, Kokkinos A, Argiana V, Katsilambros $\mathrm{N}$, Tentolouris $\mathrm{N}$. The association between cardiac autonomic neuropathy with metabolic and other factors in subjects with type 1 and type 2 diabetes. J diabet complications. 2011; 25(3):159-67.

50. Wang W, Balamurugan A, Biddle J, Rollins KM. Diabetic neuropathy status and the concerns in underserved rural communities: challenges and opportunities for diabetes educators. Diabetes educ. 2011; 37(4):536-48.
51. Palma FH, Antigual DU, Martinez SF, Monrroy MA, Gajardo RE. Static balance in patients presenting diabetes mellitus type 2 with and without diabetic polyneuropathy. Arq bras endocrinol metabol. 2013; 57(9):722-6.

52. Abrao L, Chagas JK, Schmid H. Periodontal disease and risk for neuropathic foot ulceration in type 2 diabetes. Diabetes res clin pract. 2010; 90(1):34-9.

53. Jurado J, Ybarra J, Romeo JH, Pou JM. Clinical screening and diagnosis of diabetic polyneuropathy: the North Catalonia Diabetes Study. Eur j clin invest. 2009; 39(3):183-9.

54. Mahroos FA, Roomi KA. Diabetic neuropathy, foot ulceration, peripheral vascular disease and potential risk factors among patients with diabetes in Bahrain: a nationwide primary care diabetes clinic-based study. Ann saudi med. 2007; 27(1):25-31.

55. Vaz MM, Costa GC, Reis JG, Junior WM, Paula FJA, Abreu DC. Postural control and functional strength in patients with type 2 diabetes mellitus with and without peripheral neuropathy. Arch phys med rehabil. 2013; 94(12):2465-70.

56. Sorensen L, Molyneaux L, Yue DK. Insensate versus painful diabetic neuropathy: the effects of height, gender, ethnicity and glycaemic control. Diabetes res clin pract. 2002; 57(1):45-51.

57. Cohen JA, Jeffers BW, Faldut D, Marcoux M, Schrier RW. Risks for sensorimotor peripheral neuropathy and autonomic neuropathy in non-insulin-dependent diabetes mellitus (NIDDM). Muscle nerve. 1998; 21(1):72-80.

58. Katulanda P, Ranasinghe P, Jayawardena R, Constantine GR, Sheriff $\mathrm{MH}$, Matthews DR. The prevalence, patterns and predictors of diabetic peripheral neuropathy in a developing country. Diabetol metab syndr. 2012; 4(1):21.

59. Cardoso CR, Salles GF. Predictors of development and progression of microvascular complications in a cohort of Brazilian type 2 diabetic patients. J diabetes complications. 2008; 22(3):164-70.

60. Kasim K, Amar M, Sadek AAE. Peripheral neuropathy in type-II diabetic patients attending diabetic clinics in Al-Azhar University Hospitals, Egypt. Int j diabetes mellitus. 2010.

61. Morkrid K, Ali L, Hussain A. Risk factors and prevalence of diabetic peripheral neuropathy: a study of type 2 diabetic outpatients in Bangladesh. Int $j$ diabetes dev ctries. 2010; 30(1):11.

62. Rani PK, Raman R, Rachapalli SR, Pal SS, Kulothungan V, Sharma T. Prevalence and risk factors for severity of diabetic neuropathy in type 2 diabetes mellitus. Indian j med sci. 2010; 64(2):51-7.

63. Hussain G, Rizvi SA, Singhal S, Zubair M, Ahmad J. Cross sectional study to evaluate the effect of duration of type 2 diabetes mellitus on the nerve conduction velocity in diabetic peripheral neuropathy. Diabetes metab syndr. 2014; 8(1):48-52.

64. Tapp RJ, Shaw JE, de Courten MP, Dunstan DW, Welborn TA, Zimmet PZ. Foot complications in Type 2 diabetes: an Australian population-based study. Diabet med. 2003; 20(2):105-13.

65. Abbott CA, Garrow AP, Carrington AL, Morris J, Van Ross ER, Boulton AJ. Foot ulcer risk is lower in South-Asian and africanCaribbean compared with European diabetic patients in the U.K.: the North-West diabetes foot care study. Diabetes care. 2005; 28(8):1869-75. 
66. Gadia MT, Natori N, Ramos LB, Ayyar DR, Skyler JS, Sosenko JM. Influence of height on quantitative sensory, nerve-conduction, and clinical indices of diabetic peripheral neuropathy. Diabetes care. 1987; 10(5):613-6.

67. Tesfaye S, Boulton AJ, Dyck PJ, Freeman R, Horowitz M, Kempler $P$, et al. Diabetic neuropathies: update on definitions, diagnostic criteria, estimation of severity, and treatments. Diabetes care. 2010; 33(10):2285-93.

68. Balbinot LF. Diagnóstico de neuropatia no diabetes mellitus tipo 2 e no pré-diabetes [Tese]. Porto Alegre: Universidade Federal do Rio Grande do Sul; 2012

69. Kimura J. Electrodiagnosis in diseases of nerve and muscle: principles and practice: Oxford University Press; 2013.

70. Perkins BA, Orszag A, Ngo M, Ng E, New P, Bril V. Prediction of incident diabetic neuropathy using the monofilament examination: a 4-year prospective study. Diabetes care. 2010; 33(7):1549-54.

71. Yang Z, Chen R, Zhang Y, Huang Y, Hong T, Sun F, et al. Scoring systems to screen for diabetic peripheral neuropathy - The Cochrane Collaboration. Cochrane database syst rev. 2014.

72. Arap A, Siqueira SR, Silva CB, Teixeira MJ, Siqueira JT. Trigeminal pain and quantitative sensory testing in painful peripheral diabetic neuropathy. Arch oral biol. 2010; 55(7):486-93.

Publish in International Archives of Medicine

International Archives of Medicine is an open access journal publishing articles encompassing all aspects of medical science and clinical practice. IAM is considered a megajournal with independent sections on all areas of medicine. IAM is a really international journal with authors and board members from all around the world. The journal is widely indexed and classified Q1 in category Medicine. 